OPEN ACCESS

Edited by:

Raymond Chuen-Chung Chang,

The University of Hong Kong,

Hong Kong

Reviewed by:

Heather Mack,

Eye Surgery Associates, Australia

M. Heather West Greenlee,

lowa State University, USA

Saima Hilal,

National University of Singapore,

Singapore

*Correspondence:

Maria F. Cordeiro

m.cordeiro@ucl.ac.uk

Specialty section: This article was submitted to

Neurodegeneration,

a section of the journal

Frontiers in Neurology

Received: 06 January 2016 Accepted: 29 March 2016

Published: 19 April 2016

Citation:

Javaid FZ, Brenton J, Guo L and Cordeiro MF (2016) Visual and Ocular Manifestations of Alzheimer's Disease and Their Use as Biomarkers for

Diagnosis and Progression.

Front. Neurol. 7:55.

doi: 10.3389/fneur.2016.00055

\section{Visual and Ocular Manifestations of Alzheimer's Disease and Their Use as Biomarkers for Diagnosis and Progression}

\author{
Fatimah Zara Javaid $^{1}$, Jonathan Brenton ${ }^{1}$, Li Guo $^{1}$ and Maria F. Cordeiro ${ }^{1,2 *}$ \\ ${ }^{1}$ Glaucoma and Retinal Degeneration Research Group, Visual Neurosciences, UCL Institute of Ophthalmology, London, UK, \\ ${ }^{2}$ Western Eye Hospital, Imperial College Healthcare NHS Trust, London, UK
}

Alzheimer's disease (AD) is the most common form of dementia affecting the growing aging population today, with prevalence expected to rise over the next 35 years. Clinically, patients exhibit a progressive decline in cognition, memory, and social functioning due to deposition of amyloid $\beta(A \beta)$ protein and intracellular hyperphosphorylated tau protein. These pathological hallmarks of AD are measured either through neuroimaging, cerebrospinal fluid analysis, or diagnosed post-mortem. Importantly, neuropathological progression occurs in the eye as well as the brain, and multiple visual changes have been noted in both human and animal models of AD. The eye offers itself as a transparent medium to cerebral pathology and has thus potentiated the development of ocular biomarkers for $A D$. The use of non-invasive screening, such as retinal imaging and visual testing, may enable earlier diagnosis in the clinical setting, minimizing invasive and expensive investigations. It also potentially improves disease management and quality of life for $\mathrm{AD}$ patients, as an earlier diagnosis allows initiation of medication and treatment. In this review, we explore the evidence surrounding ocular changes in $A D$ and consider the biomarkers currently in development for early diagnosis.

Keywords: Alzheimer's disease, neurodegereration, biomarkers, animal models of neurodegenerative disease, visual changes

\section{INTRODUCTION}

The growth in life expectancy and the developing aging population has led to the increased prevalence of chronic diseases, such as Alzheimer's disease (AD). Globally, there are almost 46 million people in the world living with dementia, with the number expected to rise to 131.5 million by the year 2050 (1). According to the World Health Organization (WHO) Global Burden of Disease (2004), dementia is the second largest contributor leading to total number of years living with disability (YLD) in people aged 60 years or older at $13.5 \%$, compared to heart disease $(4.0 \%)$, stroke $(4.4 \%)$, and cancer $(2.2 \%)(1)$.

Pathologically, $\mathrm{AD}$ is characterized by deposition of extracellular senile plaques, which is composed of amyloid $\beta(\mathrm{A} \beta)$ and intraneuronal neurofibrillary tangles (NFTs), resulting from intracellular aggregates of hyperphosphorylated tau protein detected in the brain (2). A $\beta$ plaque deposition is associated with cross-sectional synaptic network dysfunction, progressive brain atrophy, and longitudinal cognitive decline (3). Studies have shown that $A \beta$ and tau pathology correlates 
with neurocognition in mild cognitive impairment (MCI) (4). Less specific neuropathological lesions include granulovacuolar degeneration and eosinophilic rod-like bodies known as Hirano bodies (5).

Presently, AD can only be diagnosed post-mortem on histopathological examination. Diagnostic investigations are limited, and physicians rely on clinical examination and exclusion of differential diagnoses that may cause cognitive impairment, such as depression, Parkinson's disease (PD), hypothyroidism, drug interactions, and vitamin deficiencies (6). Clinically, a diagnosis is made based on history, examination, and where available, accounts from relatives or carers. Nevertheless, premortem diagnoses have been considered inaccurate in 10-15\% of cases even when assessed by experienced clinicians (7). Given the difficulties and delay in clinical diagnosis, patients often develop pathological damage prior to starting treatment. The advance of biomarkers using magnetic resonance imaging (MRI), positron emission tomography (PET), and cerebrospinal fluid (CSF) have led to the development of guidelines and diagnostic criteria (8-10). SPECT scanning can also be used to detect regional reduction in cerebral blood flow thought to be present in patients with AD (11).

Alzheimer's disease is a heterogeneous disease and has multiple cognitive subtypes. These are usually broken down into memory, language, executive, attention, and visuospatial functioning (12). The variant of $\mathrm{AD}$ in which visual symptoms are prominent due to the localized pathology in the parieto-occipital region is often referred to as visual variant Alzheimer's disease (VVAD) (13).

The interconnection between eye and brain suggests that it is reasonable to look for ocular manifestations of neurodegenerative disease and regard the eye as an extension of the CNS.

In embryological development, the eyes and brain have a similar origin. The eyes are formed from the anterior neural tube, an area that later gives rise to the forebrain. Ocular development occurs through specification of the eye field post-neural induction (14). This process involves specific transcription factors that are also conserved in brain development. One such factor, a "master regulator" gene of the development of the eye field, Pax6, plays an essential role in neural development. When expressed ectopically, Pax6 can induce ocular formation in other parts of the body (15), whereas its impairment or knockout disrupts neurogenesis in the cortex $(16,17)$.

In the eye, retinal neurons are comparable in many ways to their counterparts in the brain. Retinal neurons have dendrites, a soma and an axon, which are the essential neuronal features (18). They are stained by many typical neuronal markers (19-21). They form complex information processing networks similar to those in the cerebrum (22-24). The retina contains over 60 types of neuron (25) that play distinct roles in information processing. Photoreceptors represent one of the five main types of cells, the others being horizontal, bipolar, amacrine, and ganglion cell types. Photoreceptors transmit signals in a neuronal fashion when excited by light and are separated into two main subtypes, rods and cones. Bipolar cells transmit this information to retinal ganglion cells (RGCs). Horizontal cells are also connected to photoreceptors as well as bipolar cells and provide inhibitory feedback, to both adjust and refine the light signal. Amacrine cells can modify direct signals between bipolar and ganglion cells or can act as intermediaries between the two (26). In retinal networks, amacrine, bipolar, and horizontal cells act similar to interneurons, and the RGCs behave as projection neurons. Similar classes of neurotransmitters have been found in the retina, such as GABA and glutamate, which are essential to retinal information processing (27-29). Recently discovered group of retinal cell subtype are the intrinsically photosensitive retinal ganglion cells (ipRGCs). These cells respond to light through expression of the photopigment melanopsin in the absence of rod and cone photoreceptor input (30).

Therefore, due to its close association with the brain, it is not surprising that neurodegeneration caused by disorders such as Alzheimer's extends into the eye. Visual symptoms have been well documented in $\mathrm{AD}$, and there is significant evidence to illustrate that ocular pathology occurs as part of the disorder $(31,32)$. Consequently, this provides an opportunity to use a minimally invasive approach to examine the pathological features in the brain - through the transparent medium of the eye.

A critical component of research into $\mathrm{AD}$ is the use of animal models to standardize and replicate features of the disease in order to develop and assess response to treatments that would otherwise be unethical in human subjects. Approximately $98 \%$ of potential drug therapies fail in Phase 3 clinical trials, thus, pushing the focus of research toward targeting molecular pathways rather than symptom control (33). Animal models need to fit three validation criteria when used for human research (34). These are face validity, predictive validity, and constructive validity, which aim to ensure that animal model is based on relevant interpretation of the human condition.

With this in mind, many animal models have been proposed, including dog, rhesus monkey, Drosophila melanogaster, rat, and mouse (35). In particular, the mouse model is the most popular, as it has been noted to be most similar to human CNS structure in addition to its relatively inexpensive production of multiple transgenic strains (36). Transgenic mouse models of AD express single, double, or triple mutations found in familial AD. Genes encoding these mutations are presenelin 1 (PS1), presenelin 2 (PS2), tau, and amyloid precursor protein (APP). It is not the scope of this review article to detail all transgenic models available, but for the reader to have a brief background into the mutations involved.

There is a growing interest to identify a biomarker for $\mathrm{AD}$ to enable early diagnosis and prevent cognitive deterioration in patients. Genetic testing in $\mathrm{AD}$ has identified three genetic loci, APP, presenilin-1 (PSEN1), and presenilin-2 (PSEN2) as susceptibility genes for early-onset $\mathrm{AD}$ (EOAD) and SORL1 and APOE for late-onset AD (LOAD). Although these genes are useful in predicting the risk of developing $\mathrm{AD}$, their lack of diagnostic specificity and sensitivity and the influence of external environmental factors make them unsuitable as biomarkers for $\mathrm{AD}$ (37-39). The majority of research has focused on the retina and associated changes in thickness, inflammation, and cell death. Nevertheless, manifestations of AD have additionally been identified in the pupil, lens, choroid, and optic nerve, though their use in the clinical setting has not been established (Table 1). Furthermore, changes in visual function have been identified in multiple studies (Table 2) and are also being investigated as potential indicators of $\mathrm{AD}$ pathology. 
TABLE 1 | Manifestations of Alzheimer's disease (AD) in the eye.

\begin{tabular}{|c|c|}
\hline $\begin{array}{l}\text { Orbital } \\
\text { structure }\end{array}$ & Pathological changes in AD \\
\hline Pupil & $\begin{array}{l}\text { Atypical pupil response to cholinergic antagonists }(53,54) \\
\text { Lower amplitude and latency of maximum reaction of } \\
\text { pupillary light reflex (59) } \\
\text { Increased pupillary size (62) }\end{array}$ \\
\hline Lens & $\begin{array}{l}A \beta \text { in lens and aqueous humor (66) } \\
\text { Predisposition to supranuclear cataract (66) }\end{array}$ \\
\hline Retina & $\begin{array}{l}\text { Decreased retinal blood flow and RNFL thinning }(75,82,83) \\
\text { RGC degeneration particularly in superior and inferior } \\
\text { peripheral retina }(100,106) \\
\text { Overall reduction in RGC axon numbers }(26) \\
\text { A } \beta \text { deposition in retina (94) }\end{array}$ \\
\hline Choroid & Reduced choroidal thickness (101) \\
\hline Optic nerve & Increased cup: disk ratio and pallor (148-150) \\
\hline
\end{tabular}

TABLE 2 | Visual manifestations of AD.

\begin{tabular}{|c|c|c|}
\hline $\begin{array}{l}\text { Indicator of } \\
\text { vision }\end{array}$ & Manifestation of AD & $\begin{array}{l}\text { Recommended } \\
\text { clinical test }^{\mathrm{a}}\end{array}$ \\
\hline Visual acuity & $\begin{array}{l}\text { Decreased visual acuity in low } \\
\text { luminance }(32,33)\end{array}$ & HOTV chart \\
\hline $\begin{array}{l}\text { Contrast } \\
\text { sensitivity }\end{array}$ & $\begin{array}{l}\text { Reduced visual contrast sensitivity } \\
\text { particularly in low frequencies }(37,38) \\
\text { Reduced reading speed at lower } \\
\text { contrast sensitivities }(37)\end{array}$ & $\begin{array}{l}\text { Pelli-Robson } \\
\text { chart (35) } \\
\text { Michelson contrast } \\
\text { test ( } 37)\end{array}$ \\
\hline Color vision & $\begin{array}{l}\text { Poor color discrimination ( } 43) \\
\text { Deficiencies most significant in tritan } \\
\text { axis }(31,42)\end{array}$ & $\begin{array}{l}\text { City University test } \\
\text { Ishihara test (154) }\end{array}$ \\
\hline $\begin{array}{l}\text { Visual field } \\
\text { loss }\end{array}$ & Inferior hemifield loss (45) & $\begin{array}{l}\text { Humphrey automated } \\
\text { perimetry (45) } \\
\text { FDT (46) }\end{array}$ \\
\hline $\begin{array}{l}\text { Motion } \\
\text { perception }\end{array}$ & $\begin{array}{l}\text { Higher thresholds for motion detection } \\
\text { across all spatial frequencies ( } 57)\end{array}$ & $\begin{array}{l}\text { Computer animation } \\
\text { sequences using } \\
\text { random dot } \\
\text { cinematogram (57) }\end{array}$ \\
\hline $\begin{array}{l}\text { Depth } \\
\text { perception } \\
\text { and } \\
\text { stereopsis }\end{array}$ & $\begin{array}{l}\text { Reduced stereopsis, mean threshold } \\
>150 \text { s of arc }\end{array}$ & Randot stereotest (155) \\
\hline $\begin{array}{l}\text { Ocular motor } \\
\text { function }\end{array}$ & $\begin{array}{l}\text { Abnormal hypometric saccades } \\
\text { Increased latency as compared to } \\
\text { controls }(50,51)\end{array}$ & $\begin{array}{l}\text { Eye movement } \\
\text { examination (62) }\end{array}$ \\
\hline
\end{tabular}

${ }^{a} A l l$ clinical tests require patient cooperation, which can be difficult in $A D$ patients. $A D$, Alzheimer's disease; FDT, frequency doubling technique.

\section{VISUAL MANIFESTATIONS OF AD}

\section{Visual Acuity}

Many studies have found no significant difference in visual acuity between AD patients and control subjects (40). Levels of luminance may affect visual acuity, as demonstrated in $\mathrm{AD}$ patients who had decreased visual acuity under conditions of low luminance (LL) $(41,42)$. A recent study has shown that AD patients have a significantly poorer accuracy and ability in recognition of pictures in LL and low spatial frequency (LSF), compared to age-matched controls (43). Another important factor to note in $\mathrm{AD}$ patients is the increased prevalence of cataract affecting visual acuity, which is addressed later in this review (44).

\section{Contrast Sensitivity}

Contrast sensitivity allows for the ability to recognize objects over a range of spatial frequencies and is usually tested using charts (45) or electronic equipment. A deficit in this visual function greatly affects the daily functioning and quality of life and may explain the increased risk of falls and fractures in AD patients (46). AD patients have markedly reduced visual contrast sensitivity as compared to age-matched controls $(47,48)$ and are sensitive to testing even in early stages of $\mathrm{AD}$. Furthermore, donepezil, an anticholinesterase inhibitor, has been shown to improve contrast sensitivity in $\mathrm{AD}$ patients (49). A reduction in reading speed has also been noted, particularly at lower contrast sensitivities (47). Studies have also shown that reading latency is increased in $\mathrm{AD}$ patients and is more evident with irregular words in text (50).

\section{Color Vision}

Köllner first described changes in color vision, according to area of the eye affected, correlating retinal disease with blue-yellow visual changes and optic nerve disease with red-green visual loss (51). Earlier studies in AD patients have indicated that there are deficiencies in the tritan (blue) axis $(40,52)$, but more recent studies show no significant interaction in color axes (53). However, they do report an inversely proportional correlation with mini-mental state examination (MMSE) score and color discrimination error.

\section{Visual Field Loss}

Visual field (VF) loss in AD is likely attributed to the neurodegenerative changes and synaptic dysfunction, particularly due to $A \beta$ accumulation (54). Humphrey automated perimetry has been used in VF testing between AD patients and age-matched controls and has shown that the sensitivity losses occur particularly in the inferior hemifield of $\mathrm{AD}$ patients, and furthermore that degree of loss correlated with degree of dementia (55). VF testing with frequency doubling technology (FDT) also found that AD patients had VF deficits as compared to age-matched controls (56).

\section{Motion Perception}

Motion perception is the process of deducing speed and direction of elements and is vital to everyday functioning and navigation. Studies have detected higher thresholds for motion detection in $\mathrm{AD}$ patients as compared to age-matched controls, and further correlation with dementia severity (57). Another recent study looked at visual motion processing and again found that patients with $\mathrm{AD}$ had higher thresholds across all spatial and temporal frequencies (58).

\section{Depth Perception and Stereopsis}

Stereopsis is the perception of depth and 3D structure obtained from binocular vision. Studies have shown that patients with AD have reduced stereopsis as compared to control groups, and some 
also note a correlation between cognitive assessment scores and performance on stereopsis testing $(59,60)$.

\section{Ocular Motor Function}

Alzheimer's disease patients are known to have ocular motility dysfunctions and poor visual attention. They are often unable to focus on a fixed object, due to their difficulty in suppressing reflexive saccades. Crawford et al. used "eye tracking" software to assess saccadic eye movements in $\mathrm{AD}$ patients and found that they had slower reaction times as compared to the control group (61). Other studies have also shown patients with AD presented with abnormal hypometric saccades when tested, in addition to increased latency as compared to controls $(62,63)$. In particular, anti-saccades require movement of the eye in the opposite direction of a visual stimulus and suppression of the reflexive response. Functional MRI (fMRI) studies have shown patients with $\mathrm{AD}$ exhibited significantly more anti-saccade errors and, overall, demonstrated reduced activity in all oculomotor regions of the brain as compared to controls (64). The convergence angle has also been noted to be smaller and more irregular in $\mathrm{AD}$ patients (65).

\section{PUPIL}

It is now well established that patients with $\mathrm{AD}$ have an acetylcholine deficit and an altered ACh pathway (66). This became apparent in 1994 as a hypersensitive pupil response to cholinergic antagonist, tropicamide (0.01\%), was discovered (67). AD patients' pupils dilated to $13 \%$ more than controls. Subsequent experiments by Iijima et al. (68) found that significant differences in pupil sizes were found at a lower dose of tropicamide $(0.005 \%)$, potentiating the possibility for a diagnostic screening test. Scinto (69) further investigated pupil involvement in $\mathrm{AD}$ and located a clear biological link between ApoE allele status and pupillary response to dilute tropicamide. Nevertheless, the use of the tropicamide test as a diagnostic tool for $\mathrm{AD}$ is controversial, as other studies have failed to find significant results (70-72).

Another indicator of AD pathology is the pupillary light reflex (PLR). Changes in the oculomotor system of the Edinger-Westphal nucleus and degeneration in the nucleus basalis of Meynert leading to cholinergic deficit are likely to lead to changes in the pupillary system. Pupillometry using image analysis technology can provide multiple parameters from a single PLR test, such as latency to pupil reaction, constriction acceleration and velocity, and amplitude of response. Prettyman et al. first described 75\% latency of normal pupil size and the differences in constriction amplitude between AD patients and controls (73). Repetitive stimulation of the pupil light reflex over time is less pronounced in $\mathrm{AD}$ patients as compared to controls, with lower amplitude and latency of maximum reaction (74). Certain PLR measures have been found to correlate with cerebral plaque burden (75). Moreover, Bittner et al. found a significant correlation between increased pupillary size and CSF measures of both A $\beta$ and tau (76). Color pupillometry has been used to measure the response of ipRGCs in various eye disorders $(77,78)$, but not yet tested in $\mathrm{AD}$ patients. This may be a potential biomarker requiring further investigation in future studies.

\section{LENS}

Interest in the lens as an indicator of AD began after APP and A $\beta$ expression were discovered in cultured mammalian lenses (79). In animal models, $A \beta$ transgenic mice have developed lens opacification and shown to improve with EUK-189, a synthetic SOD/ catalase, demonstrating a link between $\mathrm{AD}$-associated cataracts and oxidative stress (80). Dutescu et al. also noted significant $\mathrm{A} \beta$ deposition in the lens of transgenic mice when labeling with WO2 and 1E8 antibodies, consistent with results from human studies (81).

In humans, Goldstein et al. detected the presence of $A \beta$ in the lens and aqueous humor of AD patients (82). They also found that $\mathrm{AD}$ patients had a specific cataract in the supranuclear region not present in controls, which had high reactivity and staining against $\mathrm{A} \beta$ markers and antibodies. Similar cataracts have been found in Down syndrome patients, who have an increased level of A $\beta$ due to a triplication of the APP gene (83). However, Michael et al. $(84,85)$ and Ho et al. (86) found no staining of $\mathrm{A} \beta$ in the lens of $\mathrm{AD}$ patients, although using different staining and characterization methodologies (84-86). Moreover, in a recent study, Bei et al. have concluded that opacities of the lens cannot be used as a non-invasive risk marker, as it does not vary significantly when controlling for age (87). Nonetheless, a clinical study by Kerbage et al. found that a fluorescent ligand for $\mathrm{A} \beta$ could be used in vivo to differentiate between $\mathrm{AD}$ patients and controls (88). There was a twofold greater signal in the AD patients compared to controls.

A subsequent clinical trial found the fluorescent signal of the same ligand to be able to distinguish between clinically diagnosed AD patients and controls with better results than a PET marker (89). This is a promising new development for diagnosing Alzheimer's, although few studies have investigated changes during early stages of the disease. The incidence of cataracts and $\mathrm{AD}$ increases with age. This is important to note when using the lens as a biomarker for $\mathrm{AD}$, as many patients will develop cataract irrespective of $\mathrm{AD}$ and, furthermore, may have undergone cataract surgery, thus limiting the use of the lens as a biomarker.

\section{RETINA}

\section{Retinal Vasculature}

Similar to the brain, the retina has a highly isolated and thoroughly protected vasculature (90). Since there are vascular changes in the AD brain (91), it is likely that the analogous changes may be found in the AD retina. In a preliminary study, Berisha et al. found decreased vein diameter and decreased blood flow (92). In two recent large-scale studies $(n=456)$, $\mathrm{AD}$ patients had a less complex venular structure, smaller, more sparse, and tortuous retinal vessels $(93,94)$. Furthermore, recent studies have found significantly decreased retinal venous blood flow in $\mathrm{AD}$ patients (95). Importantly, MCI patients' blood flow was found to be intermediate between AD patients and controls. This suggests that retinal blood flow (microliter per minute) might be used to monitor disease progression. They also observed that retinal nerve fiber layer 
(RNFL) thickness was decreased, but not significantly between $\mathrm{AD}$ patients and both MCI and control groups. This suggests that blood flow changes may precede cell death in the retina. Retinal oximetry is used to detect changes in eye metabolism and has been noted in a recent study to show abnormalities in AD. Einarsdottir et al. found that retinal oxygen saturation in arterioles and venules was elevated in $\mathrm{AD}$ patients as compared to controls (96).

\section{Retinal Thickness}

Early histopathological studies implicated RGCs as the primary targets of cell loss in AD (97). As they demonstrated that the outer layers were relatively preserved in the postmortem retinas of $\mathrm{AD}$ patients, measurements have predominantly focused on the RNFL. Imaging technology, such as optical coherence tomography (OCT), has recently illustrated further evidence of RGC degeneration in vivo through measurement of the RNFL, indirectly evidencing ganglion cell loss (92, 98-100). An initial study by Parisi et al. found decreased RNFL thickness in all four retinal quadrants (101). RNFL thinning correlated with patients' pattern electroretinogram performance, suggesting that RNFL thinning is related to visual dysfunction in AD. Current evidence also suggests that RNFL thickness decreases as the disease progresses and that there is a significant correlation between overall macula volume and level of cognitive impairment measured by the MMSE (102). Studies have shown significant differences not only between MCI patients and controls but also between MCI patient's and two other $\mathrm{AD}$ groups (moderate and severe $\mathrm{AD}$ ) in superior and total RNFL thickness (103). A recent meta-analysis (104) of $11 \mathrm{AD}$ OCT studies found significant reduction in mean RNFL and in all 4 individual retinal quadrants around the $\mathrm{AD}$ macula. In three of these studies containing MCI patients, decreased RNFL thickness was found compared to controls. Bambo et al. also noted significant RNFL thinning in the superior and inferior quadrants of AD patients (105).

A few animal studies have published similar findings with regards to neuronal cell loss in the RGCL. One study using a single transgenic mouse model reported a statistically significant decrease in the retinal thickness of the $\mathrm{Tg} 2576$ mice from the GCL to the ONL as compared to wild-type control animals (106). This suggests that retinal degeneration may affect all retinal cell types and layers.

Recently, Ong et al. (107) combined the use of OCT and MRI scanning in an elderly population ( $>60$ years old). They discovered that decreases in GC-IPL thickness correlated with decreased size of the occipital and temporal regions of the brain. These correlations suggest that degeneration in the retina is paralleled in specific regions of the brain, which are implicated in AD.

\section{$\mathbf{A} \beta$ in the Retina}

Synaptic dysfunction and neuronal cell death because of A $\beta$ toxic deposits are pathological hallmarks of AD (54). In animal models, overexpression of the human APP Swedish gene in $\operatorname{Tg} 2576$ mouse results in deposition of $A \beta$ plaques in the brain (81). This strain of mice developed memory deficits at 10 months of age as compared to the APPswe/PS1-del9 transgenic strain that developed deficits earlier at 6 months of age (108). A $\beta$ plaques have
TABLE 3 | Location of APP and A $\beta$ found in the animal retina.

\begin{tabular}{lccc}
\hline Retinal layer & APP & A $\beta$ & Tau \\
\hline Retinal pigment epithelium & - & - & - \\
Outer nuclear layer & - & + & - \\
Inner nuclear layer & + & + & - \\
Inner plexiform layer & + & + & - \\
Ganglion cell layer & + & + & + \\
\hline +Present. & & & \\
-Absent. & & & \\
APP has been found in the ganglion cell layer through the inner nuclear layer in AD \\
animal models (65, 81, 86, 106). A has been found in the retina in all layers apart from \\
the retinal pigment epithelium (81, 88, 93, 109, 114). Tau has been found in ganglion \\
cell layer (99, 106, 133).
\end{tabular}

since been reported in the same strain, from the ganglion cell layer to the inner plexiform layer, in addition to plaques found in the outer segment and optic nerve $(106,109)$ (Table 3$)$. Thus, this model suggests that ganglion cells and potentially retinal interneurons (horizontal, bipolar, and amacrine cells) are affected by $A \beta$ plaques; yet, all retinal cells may be compromised in later stages of the disorder.

Amyloid $\beta$ loads are further associated with immunoreactivity for MCP-1, F4/80, and TUNEL-positive profiles in the RGC layer in mutant presenilin (PS1) and APP transgenic mice. This further indicates that $\mathrm{A} \beta$ deposition causes retinal neurodegeneration in mouse models of AD (110). Transgenic mice overexpressing the Swedish mutation (APP23) and mutant human APP and mutant human presenilin-1 (APPPS1) exhibit a threefold increase in total endogenous murine Tau in CSF and an age-related increase in $\mathrm{A} \beta$ deposition (111).

In vivo imaging in APP/PS1 transgenic mice following administration of systemic curcumin has provided a potential tool for monitoring $\mathrm{A} \beta$ plaque formation in $\mathrm{AD}$ (112). Optical imaging showed increased plaque formation with age in the mouse model, and remarkably, a decrease in response to glatiramer acetate immunotherapy. APP and A $\beta$ have both been located in the human retina (113); however, these were not consistently found (32). A major advance was made in 2011 in human $\mathrm{AD}$, where $\mathrm{A} \beta$ was visualized in the postmortem retina and also live animal retina (114). Very recent work has revealed substantial $A \beta$ deposition in postmortem $\mathrm{AD}$ retinas and that these deposits may preferentially target the melanopsin-staining subtype of RGC (115).

Amyloid $\beta$ has been identified in retinal drusen, a hallmark of age-related macular degeneration (AMD), a major cause of worldwide blindness. Drusen are abnormal extracellular deposits along the basal surface of the retinal pigmented epithelium (RPE). A $\beta$-containing drusen are associated with RPE atrophy and photoreceptor death $(116,117)$. In AMD, they are predominantly located in the macula at the center of the retina, but they can still occur peripherally. In fact, peripheral drusen have been found to be significantly associated with $\operatorname{AD}(118,119)$.

It is believed that $\mathrm{A} \beta$ can enter the RPE through advanced glycation end products (RAGE)/p38 MAPK-mediated endocytosis. Intracellular $\mathrm{A} \beta$ triggers breakdown of RPE tight junctions (120), as described in Tg AD mice (121). The toxic effects of $A \beta$ on RPE include reduced mitochondrial redox potential and increased 
reactive oxygen species (ROS) production, RPE pigmentation and hypertrophy, followed by photoreceptor death (122). In addition, $\mathrm{A} \beta$-mediated gliosis of Müller cells (MCs) has been implicated in retinal degeneration. MCs are the principal retinal glial cells and metabolically coupled to photoreceptors. Glial cell activation in response to $A \beta$ deposition has compromised the integrity of the blood-retina barrier, leading to photoreceptor apoptosis (123). Interestingly, $A \beta$ did not induce cell death in purified photoreceptor cell cultures but in mixed retinal cell cultures, suggesting that the cellular environment plays a role in $\mathrm{A} \beta$-mediated photoreceptor apoptosis (124). Furthermore, A $\beta$ has been implicated in complement activation by upregulating factor $\mathrm{B}$, the main activator of the complement alternative pathway, in RPE through cytokines, which are released from recruited macrophages/ microglia (125). This may explain the colocalization of A $\beta$ with activated complement components found in some drusen (126, 127). Similar observations have also been reported in senile $A \beta$ plaques in the brain, where $A \beta$ is thought to be a primary activator of complement in $\mathrm{AD}$ (128), suggesting common mechanisms may be applied to $\mathrm{AD}$, drusen formation, and $\mathrm{AMD}$.

\section{Tau in the Retina}

Tau accumulation has been observed in brains of doubly transgenic mice from 4.5 months of age (129) and in the hippocampus and amygdala of triple-transgenic mice (130). In single Tg2576 transgenic mice (APP), hyperphosphorylated tau was observed in adjacent sections of $\mathrm{A} \beta$ deposition in the ganglion cell layer (106). Double-transgenic mice APP/PS1 also displayed hyperexpression of tau in the retina with consequent upregulation of $\mathrm{p} 35$, p25, and calpain, which has been widely hypothesized to cause synaptic dysfunction and calcium dysregulation in the context AD-related apoptosis $(131,132)$. In human P301S tau transgenic mice, tau aggregates formed in the RNFL resulting in axonopathy and at 2 months of age formed tau inclusions within RGC (133). Tau has been found in the human retina (113); yet, this finding has not been consistently replicated $(86,134)$.

\section{Retinal Fluorescence and Neurodegeneration}

In animal models, retinal changes observed in double-transgenic mice included accumulation of $\mathrm{A} \beta$ peptides in addition to detection of apoptotic cells in the RGC layer (135). Another study using the double-transgenic model $(\mathrm{Tg} 2576 \times \mathrm{Tg} 1)$ observed that 27 -month-old mice had a $200 \%$ increase in the number of apoptosing cells in the GCL, as compared to 7.8-month-old mice (110).

A more extensive triple-transgenic mouse model expressing human APP, PS1, and tau mutations was used to investigate retinal glial changes in $\mathrm{AD}$. The study by Edwards et al. found that at 9 months, MCs were activated, and astrocytes increased in size and number indicating retinal glial activation (136). Further evidence for involvement of the outer retina in $\mathrm{AD}$ models of disease is depicted in transgenic AD rat models. Tsai et al. found on staining of retinal sections that RPE cells showed marked hypertrophy and frequently contained two nuclei rather than one (137).
In vivo imaging has recently developed to allow direct visualization of apoptosing cells in the retina. A novel technique has been established using radiolabeled annexin $\mathrm{V}$ and confocal laser scanning ophthalmoscopy to detect cell apoptosis in the retina (138). This in vivo imaging method is known as detection of apoptosing retinal cells (DARC). Using this imaging technique and applying it to animal models provides further evidence of RGC apoptosis in AD. Following PI and annexin-IR intravitreal injection in triple-transgenic $\mathrm{AD}$ mice, a significant number of RGCs were observed to undergo early-phase apoptosis as compared to age-matched controls (139).

A small pilot study using retinal fluorescence lifetime imaging ophthalmoscopy (FLIO) suggested that retinal changes detected by FLIO correlated with clinical characteristics of AD and could potentially be used as a biomarker for AD. However, the lack of control group and small study size warrants further research before attributing these general changes specifically to AD (140). Another study used systemic curcumin administration followed by optical imaging to successfully label retinal $\mathrm{A} \beta$ plaques in mice (114). This has also been trialed in patients using curcumin supplements and retinal fluorescence imaging (141). Furthermore, recent research has established methods of identifying drusen deposits in the peripheral retina using ultra-wide-field imaging $(142,143)$. This is particularly of note in patients with $\mathrm{AD}$, as these small deposits were not found in age-matched controls, thus providing possibility for another potential biomarker for diagnosis of early AD.

\section{CHOROID}

Most research has been directed toward retinal changes in $\mathrm{AD}$ given the direct association with the brain. However, a few studies have observed possible choroidal manifestations of AD in animal models. Heterozygous transgenic rats (TgF344-AD) had significantly reduced choroidal thickness as compared to age-matched controls (137). Also, of note in this particular study was the upregulation of complement factor $\mathrm{C} 3$, which has previously been noted to play a role in RGC related apoptosis, studied particularly in glaucoma (144). Ning et al. also reported age-dependent A $\beta$ deposits in the retinal and choroidal vasculature of two strains of transgenic mice (110).

In human models, recent imaging of the choroid in $\mathrm{AD}$ patients showed decreased choroidal thickness (145). However, given the limited research undertaken, more studies are needed to confirm if the choroid is indeed damaged in $\mathrm{AD}$.

\section{OPTIC NERVE AND NEURODEGENERATION}

Cell death of RGC and changes in the optic nerve head have long been noted in postmortem $\mathrm{AD}$ retinas and first described by Hinton et al. who found a variety of degenerative profiles in RGCs, including cell shrinkage and cell swelling with vacuolization (97). Moreover, there was a two to threefold reduction in RGC axon numbers compared to controls. Further research (146) found the same features of degeneration in addition to 
nuclear fragmentation and heavily silver-stained cytoplasm. It was also noted that $\mathrm{AD}$ optic nerves had approximately half the RGC axon density of controls (32). This suggests that the larger "M" cell type RGCs are chiefly affected by AD. Blanks et al. found a $25 \%$ reduction of RGCs in the central $3 \mathrm{~mm}$ of the AD retina and severe cell loss over the entire retina $(134,147)$. This degeneration is more pronounced in the superior and inferior peripheral regions.

More recently, new imaging technologies have provided in vivo evidence of optic nerve head pathology. Multiple studies, using OCT and confocal laser scanning, have found greater cup-to-disk ratio and increased pallor of the $\mathrm{AD}$ optic nerve, representing a significant loss of RGC axons (148-151).

\section{FUTURE IMPLICATIONS}

As outlined earlier in this review article, specialist brain imaging modalities, such as fMRI and PET scanning, can support a diagnosis of $\mathrm{AD}$. Unfortunately, these are expensive investigative techniques and are often limited to a hospital setting. Furthermore, changes in the brain are often a sign of later-stage $\mathrm{AD}$ and symptoms of cognitive decline will already have set in. Remarkably, studies now support the hypothesis that $A \beta$ plaques appear earlier in the retina (114) and so propose the possibility for earlier diagnosis of $\mathrm{AD}$ and subsequent treatment.

Alzheimer's disease-related retinal degeneration has provided a novel technique for investigating $\mathrm{AD}$ pathology and targeting

\section{REFERENCES}

1. Prince PM, Ali G, Ali G. World Alzheimer Report 2015. The Global Impact of Dementia. London: Alzheimers Disease International (2015).

2. Bloom GS. Amyloid- $\beta$ and tau: the trigger and bullet in Alzheimer disease pathogenesis. JAMA Neurol (2014) 71:505-8. doi:10.1001/ jamaneurol.2013.5847

3. Jagust W. Is amyloid- $\beta$ harmful to the brain? Insights from human imaging studies. Brain (2015) 139:23-30. doi:10.1093/brain/awv326

4. Malpas CB, Saling MM, Velakoulis D, Desmond P, O’Brien TJ; Alzheimer's Disease Neuroimaging Initiative. Tau and amyloid- $\beta$ cerebrospinal fluid biomarkers have differential relationships with cognition in mild cognitive impairment. J Alzheimers Dis (2015) 47:965-75. doi:10.3233/JAD-142643

5. Ha S, Furukawa R, Stramiello M, Wagner JJ, Fechheimer M. Transgenic mouse model for the formation of Hirano bodies. BMC Neurosci (2011) 12:97. doi:10.1186/1471-2202-12-97

6. Burns A, Zaudig M. Mild cognitive impairment in older people. Lancet (2002) 360:1963-5. doi:10.1016/S0140-6736(02)11920-9

7. Thal LJ, Kantarci K, Reiman EM, Klunk WE, Weiner MW, Zetterberg H, et al. The role of biomarkers in clinical trials for Alzheimer disease. Alzheimer Dis Assoc Disord (2007) 20:6-15. doi:10.1097/01.wad.0000191420.61260.a8

8. McKhann GM, Knopman DS, Chertkow H, Hyman BT, Jack CR Jr, Kawas CH, et al. The diagnosis of dementia due to Alzheimer's disease: recommendations from the National Institute on Aging-Alzheimer's Association workgroups on diagnostic guidelines for Alzheimer's disease. Alzheimers Dement (2011) 7:263-9. doi:10.1016/j.jalz.2011.03.005

9. Albert MS, DeKosky ST, Dickson D, Dubois B, Feldman HH, Fox NC, et al. The diagnosis of mild cognitive impairment due to Alzheimer's disease: recommendations from the National Institute on Aging and Alzheimer's Association workgroup. Alzheimers Dement (2011) 7:270-9. doi:10.1016/j. jalz.2011.03.008

10. Hyman BT, Phelps CH, Beach TG, Bigio EH, Cairns NJ, Carrillo MC, et al. National Institute on Aging-Alzheimer's Association guidelines for the treatment. Multiple human and animal studies have illustrated the correlation of $\mathrm{AD}$ neuropathology in the retina and the brain, including $A \beta$ and tau accumulation, neuronal cell loss, and RGC apoptosis. Using the eye and its transparent medium as an "extension of the brain" allows for non-invasive visualization of AD pathology in vivo, and enables monitoring of biomarkers in order to diagnose and potentially monitor development and treatment of $\mathrm{AD}$.

Technology, such as DARC, has provided a platform for this (139), and different approaches to in vivo imaging are constantly evolving $(114,143,152)$. Unfortunately, these methods of in vivo imaging are not without limitations, particularly with regards to specificity for $\mathrm{A} \beta$ plaques. Currently, the use of OCT to assess the ONH and RNFL are useful in detecting neurodegeneration, in addition to a comprehensive eye examination in the clinical setting covering VF defects, pupillometry, and contrast sensitivity. In vivo imaging is emerging as a potential biomarker in many neurodegenerative diseases $(138,153)$, and the evolution and development of such imaging techniques today prove promising as diagnostic tools of the future.

\section{AUTHOR CONTRIBUTIONS}

FJ: preparation of manuscript, editing, proofing and submitting author; JB: preparation of manuscript, editing; LG: editing manuscript; MC: overall editing and corresponding author.

neuropathologic assessment of Alzheimer's disease. Alzheimers Dement (2013) 8:1-13. doi:10.1016/j.jalz.2011.10.007

11. Takahashi H, Ishii K, Hosokawa C, Hyodo T, Kashiwagi N, Matsuki M, et al. Clinical application of $3 \mathrm{D}$ arterial spin-labeled brain perfusion imaging for Alzheimer disease: comparison with brain perfusion SPECT. AJNR Am J Neuroradiol (2014) 35:906-11. doi:10.3174/ajnr.A3780

12. Scheltens NM, Galindo-Garre F, Pijnenburg YA, van der Vlies AE, Smits LL, Koene T, et al. The identification of cognitive subtypes in Alzheimer's disease dementia using latent class analysis. J Neurol Neurosurg Psychiatry (2015) 87(3):235-43. doi:10.1136/jnnp-2014-309582

13. Kaeser P-F, Ghika J, Borruat F-X. Visual signs and symptoms in patients with the visual variant of Alzheimer disease. BMC Ophthalmol (2015) 15:65. doi:10.1186/s12886-015-0060-9

14. Chow RL, Lang RA. Early eye development in vertebrates. Annu Rev Cell Dev Biol (2001) 17:255-96. doi:10.1146/annurev.cellbio.17.1.255

15. Gehring WJ. The master control gene for morphogenesis and evolution of the eye. Genes Cells (1996) 1:11-5. doi:10.1046/j.1365-2443.1996.11011.x

16. Tuoc TC, Radyushkin K, Tonchev AB, Piñon MC, Ashery-Padan R, Molnár Z, et al. Selective cortical layering abnormalities and behavioral deficits in cortex-specific Pax6 knock-out mice. J Neurosci (2009) 29:8335-49. doi:10.1523/ JNEUROSCI.5669-08.2009

17. Heins N, Malatesta P, Cecconi F, Nakafuku M, Tucker KL, Hack MA, et al. Glial cells generate neurons: the role of the transcription factor Pax6. Nat Neurosci (2002) 5:308-15. doi:10.1038/nn828

18. London A, Benhar I, Schwartz M. The retina as a window to the brain - from eye research to CNS disorders. Nat Rev Neurol (2013) 9:44-53. doi:10.1038/ nrneurol.2012.227

19. Okabe S, Shiomura Y, Hirokawa N. Immunocytochemical localization of microtubule-associated proteins $1 \mathrm{~A}$ and 2 in the rat retina. Brain Res (1989) 483:335-46. doi:10.1016/0006-8993(89)90178-9

20. Ma W, Wang S-Z. The final fates of neurogenin2-expressing cells include all major neuron types in the mouse retina. Mol Cell Neurosci (2006) 31:463-9. doi:10.1016/j.mcn.2005.10.018 
21. Sharma RK, Netland PA. Early born lineage of retinal neurons express class III $\beta$-tubulin isotype. Brain Res (2007) 1176:11-7. doi:10.1016/j.brainres. 2007.07.090

22. Wong RO, Chernjavsky A, Smith SJ, Shatz CJ. Early functional neural networks in the developing retina. Nature (1995) 374:716-8. doi:10.1038/374716a0

23. Thoreson WB, Mangel SC. Lateral interactions in the outer retina. Prog Retin Eye Res (2012) 31:407-41. doi:10.1016/j.preteyeres.2012.04.003

24. Ganmor E, Segev R, Schneidman E. The architecture of functional interaction networks in the retina. J Neurosci (2011) 31:3044-54. doi:10.1523/ JNEUROSCI.3682-10.2011

25. Masland RH. The neuronal organization of the retina. Neuron (2012) 76:266-80. doi:10.1016/j.neuron.2012.10.002

26. Kolb H. How the retina works» American Scientist. Am Sci (2003) 91:28-34. doi:10.1511/2003.1.28

27. Crooks J, Kolb H. Localization of GABA, glycine, glutamate and tyrosine hydroxylase in the human retina. J Comp Neurol (1992) 315:287-302. doi:10.1002/cne. 903150305

28. Thoreson WB, Witkovsky P. Glutamate receptors and circuits in the vertebrate retina. Prog Retin Eye Res (1999) 18:765-810. doi:10.1016/ S1350-9462(98)00031-7

29. Kalloniatis M, Loh CS, Acosta ML, Tomisich G, Zhu Y, Nivison-Smith L, et al. Retinal amino acid neurochemistry in health and disease. Clin Exp Optom (2013) 96:310-32. doi:10.1111/cxo.12015

30. Pickard GE, Sollars PJ. Intrinsically photosensitive retinal ganglion cells. Rev Physiol Biochem Pharmacol (2012) 162:59-90. doi:10.1007/112_2011_4

31. Katz B, Rimmer S. Ophthalmologic manifestations of Alzheimer's disease. Surv Ophthalmol (1989) 34:31-43. doi:10.1016/0039-6257(89)90127-6

32. Sadun AA, Bassi CJ. Optic nerve damage in Alzheimer's disease. Ophthalmology (1990) 97:9-17. doi:10.1016/S0161-6420(90)32621-0

33. Cummings JL, Morstorf T, Zhong K. Alzheimer's disease drug-development pipeline: few candidates, frequent failures. Alzheimers Res Ther (2014) 6:37. doi:10.1186/alzrt269

34. Willner P. Validation criteria for animal models of human mental disorders: learned helplessness as a paradigm case. Prog Neuropsychopharmacol Biol Psychiatry (1986) 10:677-90. doi:10.1016/0278-5846(86)90051-5

35. Laurijssens B, Aujard F, Rahman A. Animal models of Alzheimer's disease and drug development. Drug Discov Today Technol (2013) 10:e319-27. doi:10.1016/j.ddtec.2012.04.001

36. Parnell M, Guo L, Abdi M, Cordeiro MF. Ocular manifestations of Alzheimer's disease in animal models. Int J Alzheimers Dis (2012) 2012:786494. doi: $10.1155 / 2012 / 786494$

37. Slooter AJ, Cruts M, Kalmijn S, Hofman A, Breteler MM, Van Broeckhoven C, et al. Risk estimates of dementia by apolipoprotein E genotypes from a population-based incidence study: the Rotterdam Study. Arch Neurol (1998) 55:964-8. doi:10.1001/archneur.55.7.964

38. Huang W, Qiu C, von Strauss E, Winblad B, Fratiglioni L. APOE genotype, family history of dementia, and Alzheimer disease risk: a 6-year follow-up study. Arch Neurol (2004) 61:1930-4. doi:10.1001/archneur.61.12.1930

39. Blacker D. New insights into genetic aspects of Alzheimer's disease. Does genetic information make a difference in clinical practice? Postgrad Med (2000) 108:119-22. doi:10.3810/pgm.2000.10.1267

40. Rizzo M, Anderson SW, Dawson J, Nawrot M. Vision and cognition in Alzheimer's disease. Neuropsychologia (2000) 38:1157-69. doi:10.1016/ S0028-3932(00)00023-3

41. Lakshminarayanan V, Lagrave J, Kean ML, Dick M, Shankle R. Vision in dementia: contrast effects. Neurol Res (1996) 18:9-15.

42. Cormack FK, Tovee M, Ballard C. Contrast sensitivity and visual acuity in patients with Alzheimer's disease. Int J Geriatr Psychiatry (2000) 15:614-20. doi:10.1002/1099-1166(200007)15:7<614::AID-GPS153>3.3.CO;2-S

43. Lee Y-T, Pai M-C. Recognition of personality familiar scenes in patients with very mild Alzheimer's disease: effects of spatial frequency and luminance. J Alzheimers Dis (2012) 29:441-8. doi:10.3233/JAD-2011-111601

44. Jefferis JM, Mosimann UP, Clarke MP. Cataract and cognitive impairment: a review of the literature. Br J Ophthalmol (2011) 95:17-23. doi:10.1136/ bjo.2009.165902

45. Pelli DG, Robson JG. The design of a new letter chart for measuring contrast sensitivity. Clin Vision Sci (1988) 2:187-99.

46. Klein BEK, Moss SE, Klein R, Lee KE, Cruickshanks KJ. Associations of visual function with physical outcomes and limitations 5 years later in an older population: the Beaver Dam eye study. Ophthalmology (2003) 110:644-50. doi:10.1016/S0161-6420(02)01935-8

47. Gilmore GC, Groth KE, Thomas CW. Stimulus contrast and word reading speed in Alzheimer's disease. Exp Aging Res (2006) 31:15-33. doi:10.1080/03610730590882828

48. Risacher SL, Wudunn D, Pepin SM, MaGee TR, McDonald BC, Flashman LA, et al. Visual contrast sensitivity in Alzheimer's disease, mild cognitive impairment, and older adults with cognitive complaints. Neurobiol Aging (2013) 34:1133-44. doi:10.1016/j.neurobiolaging.2012.08.007

49. Boucart M, Bubbico G, Szaffarczyk S, Defoort S, Ponchel A, Waucquier N, et al. Donepezil increases contrast sensitivity for the detection of objects in scenes. Behav Brain Res (2015) 292:443-7. doi:10.1016/j.bbr.2015.06.037

50. Passafiume D, Di Giacomo D, Giubilei F. Reading latency of words and nonwords in Alzheimer's patients. Cortex (2000) 36:293-8. doi:10.1016/ S0010-9452(08)70531-8

51. Köllner H. Die Störungen Des Farbensinnes Ihre Klinische Bedeutung Und Ihre Diagnose. Am JMed Sci (1912) 144.5:747. doi:10.1097/00000441191211000-00018

52. Cronin-Golomb A, Sugiura R, Corkin S, Growdon JH. Incomplete Achromatopsia in Alzheimer's disease. Neurobiol Aging (1993) 14:471-7. doi:10.1016/0197-4580(93)90105-K

53. Salamone G, Di Lorenzo C, Mosti S, Lupo F, Cravello L, Palmer K, et al. Color discrimination performance in patients with Alzheimer's disease. Dement Geriatr Cogn Disord (2009) 27:501-7. doi:10.1159/000218366

54. Bateman R. Alzheimer's disease and other dementias: advances in 2014 Lancet Neurol (2015) 14:4-6. doi:10.1016/S1474-4422(14)70301-1

55. Trick GL, Trick LR, Morris P, Wolf M. Visual field loss in senile dementia of the Alzheimer's type. Neurology (1995) 45:68-74. doi:10.1212/ WNL.45.1.68

56. Valenti DA. Alzheimer's disease: screening biomarkers using frequency doubling technology visual field. ISRN Neurol (2013) 2013:989583. doi:10.1155/2013/989583

57. Gilmore GC, Wenk HE, Naylor LA, Koss E. Motion perception and Alzheimer's disease. J Gerontol (1994) 49:52-7. doi:10.1093/ geronj/49.2.P52

58. Kavcic V, Vaughn W, Duffy CJ. Distinct visual motion processing impairments in aging and Alzheimer's disease. Vision Res (2011) 51:386-95. doi:10.1016/j.visres.2010.12.004

59. Lee C, Ko D, Suh Y, Park K. Cognitive functions and stereopsis in patients with Parkinson's disease and Alzheimer's disease using 3-dimensional television: a case controlled trial. PLoS One (2015) 10(3):e0123229. doi:10.1371/ journal.pone. 0123229

60. Lee AG, Martin CO. Neuro-ophthalmic findings in the visual variant of Alzheimer's disease. Ophthalmology (2004) 111:371-6. doi:10.1016/ S0161-6420(03)00732-2

61. Crawford TJ, Devereaux A, Higham S, Kelly C. The disengagement of visual attention in Alzheimer's disease: a longitudinal eye-tracking study. Front Aging Neurosci (2015) 7:118. doi:10.3389/fnagi.2015.00118

62. Scinto LF, Daffner KR, Castro L, Weintraub S, Vavrik M, Mesulam MM. Impairment of spatially directed attention in patients with probable Alzheimer's disease as measured by eye movements. Arch Neurol (1994) 51:682-8. doi:10.1001/archneur.1994.00540190062016

63. Garbutt S, Matlin A, Hellmuth J, Schenk AK, Johnson JK, Rosen H, et al. Oculomotor function in frontotemporal lobar degeneration, related disorders and Alzheimer's disease. Brain (2008) 131:1268-81. doi:10.1093/brain/ awn 047

64. Wright S, MacAskill M. Antisaccades in Alzheimer's disease using fMRI. Alzheimers Dement (2012) 8:51. doi:10.1016/j.jalz.2012.05.120

65. Uomori K, Murakami S, Yamada M, Fujii M, Yoshimatsu H, Nakano N, et al. Analysis of gaze shift in-depth in Alzheimers-disease patients. IEICE Trans Inf Syst (1993) E76D:963-73.

66. Shen J, Wu J. Nicotinic Cholinergic Mechanisms in Alzheimer's Disease. Nicotine Use in Mental Illness and Neurological Disorders. Oxford: Elsevier Inc. (2015). $124 \mathrm{p}$.

67. Scinto LF, Daffner KR, Dressler D, Ransil BI, Rentz D, Weintraub S, et al. A potential noninvasive neurobiological test for Alzheimer's disease. Science (1994) 266:1051-4. doi:10.1126/science.7973660

68. Iijima A, Haida M, Ishikawa N, Ueno A, Minamitani H, Shinohara Y. Re-evaluation of tropicamide in the pupillary response test for Alzheimer's 
disease. Neurobiol Aging (2003) 24:789-96. doi:10.1016/S0197-4580(02) 00235-X

69. Scinto LFM. ApoE allelic variability influences pupil response to cholinergic challenge and cognitive impairment. Genes Brain Behav (2007) 6:209-15. doi:10.1111/j.1601-183X.2006.00247.x

70. Kardon R. Drop the Alzheimer's drop test. Neurology (1998) 50:588-91. doi:10.1212/WNL.50.3.588

71. Graff-Radford NR, Lin SC, Brazis PW, Bolling JP, Liesegang TJ, Lucas JA, et al. Tropicamide eyedrops cannot be used for reliable diagnosis of Alzheimer's disease. Mayo Clin Proc (1997) 72:495-504. doi:10.4065/72.6.495

72. Growdon JH, Graefe K, Tennis M, Hayden D, Schoenfeld D, Wray SH. Pupil dilation to tropicamide is not specific for Alzheimer disease. Arch Neurol (1997) 54:841-4. doi:10.1001/archneur.1997.00550190031011

73. Prettyman R, Bitsios P, Szabadi E. Altered pupillary size and darkness and light reflexes in Alzheimer's disease. J Neurol Neurosurg Psychiatry (1997) 62:665-8. doi:10.1136/jnnp.62.6.665

74. Granholm E, Morris S, Galasko D, Shults C, Rogers E, Vukov B. Tropicamide effects on pupil size and pupillary light reflexes in Alzheimer's and Parkinson's disease. Int J Psychophysiol (2003) 47:95-115. doi:10.1016/ S0167-8760(02)00122-8

75. Frost S, Kanagasingam Y, Sohrabi HR, Taddei K, Bateman R, Morris J, et al. Pupil response biomarkers distinguish amyloid precursor protein mutation carriers from non-carriers. Curr Alzheimer Res (2013) 10:790-6. doi:10.217 4/15672050113109990154

76. Bittner DM, Wieseler I, Wilhelm H, Riepe MW, Muller NG. Repetitive pupil light reflex: potential marker in Alzheimer's disease? J Alzheimers Dis (2014) 42:1469-77. doi:10.3233/JAD-140969

77. Herbst K, Sander B, Lund-Andersen H, Wegener M, Hannibal J, Milea D. Unilateral anterior ischemic optic neuropathy: chromatic pupillometry in affected, fellow non-affected and healthy control eyes. Front Neurol (2013) 4:52. doi:10.3389/fneur.2013.00052

78. Nissen C, Sander B, Milea D, Kolko M, Herbst K, Hamard P, et al. Monochromatic pupillometry in unilateral glaucoma discloses no adaptive changes subserved by the ipRGCs. Front Neurol (2014) 5:15. doi:10.3389/ fneur.2014.00015

79. Frederikse PH, Garland D, Zigler JS, Piatigorsky J. Oxidative stress increases production of beta-amyloid precursor protein and beta-amyloid (Abeta) in mammalian lenses, and Abeta has toxic effects on lens epithelial cells. J Biol Chem (1996) 271:10169-74. doi:10.1074/jbc.271.17.10169

80. Melov S, Wolf N, Strozyk D, Doctrow SR, Bush AI. Mice transgenic for Alzheimer disease beta-amyloid develop lens cataracts that are rescued by antioxidant treatment. Free Radic Biol Med (2005) 38:258-61. doi:10.1016/j. freeradbiomed.2004.10.023

81. Dutescu RM, Li QX, Crowston J, Masters CL, Baird PN, Culvenor JG. Amyloid precursor protein processing and retinal pathology in mouse models of Alzheimer's disease. Graefes Arch Clin Exp Ophthalmol (2009) 247:1213-21. doi:10.1007/s00417-009-1060-3

82. Goldstein LE, Muffat JA, Cherny RA, Moir RD, Ericsson MH, Huang X, et al. Cytosolic beta-amyloid deposition and supranuclear cataracts in lenses from people with Alzheimer's disease. Lancet (2003) 361:1258-65. doi:10.1016/ S0140-6736(03)12981-9

83. Moncaster JA, Pineda R, Moir RD, Lu S, Burton MA, Ghosh JG, et al. Alzheimer's disease amyloid-beta links lens and brain pathology in Down syndrome. PLoS One (2010) 5:e10659. doi:10.1371/journal.pone.0010659

84. Michael R, Rosandić J, Montenegro GA, Lobato E, Tresserra F, Barraquer RI, et al. Absence of beta-amyloid in cortical cataracts of donors with and without Alzheimer's disease. Exp Eye Res (2013) 106:5-13. doi:10.1016/j. exer.2012.10.012

85. Michael R, Otto C, Lenferink A, Gelpi E, Montenegro GA, Rosandić J, et al. Absence of amyloid-beta in lenses of Alzheimer patients: a confocal Raman microspectroscopic study. Exp Eye Res (2014) 119:44-53. doi:10.1016/j. exer.2013.11.016

86. Ho C-Y, Troncoso JC, Knox D, Stark W, Eberhart CG. Beta-amyloid, phospho-tau and alpha-synuclein deposits similar to those in the brain are not identified in the eyes of Alzheimer's and Parkinson's disease patients. Brain Pathol (2014) 24:25-32. doi:10.1111/bpa.12070

87. Bei L, Shui YB, Bai F, Nelson SK, Van Stavern GP, Beebe DC. A test of lens opacity as an indicator of preclinical Alzheimer disease. Exp Eye Res (2015) 140:117-23. doi:10.1016/j.exer.2015.03.010
88. Kerbage C, Sadowsky CH, Jennings D, Cagle GD, Hartung PD. Alzheimer's disease diagnosis by detecting exogenous fluorescent signal of ligand bound to Beta amyloid in the lens of human eye: an exploratory study. Front Neurol (2013) 4:62. doi:10.3389/fneur.2013.00062

89. Kerbage C, Sadowsky CH, Tariot PN, Agronin M, Alva G, Turner FD, et al. Detection of Amyloid $\beta$ signature in the lens and its correlation in the brain to aid in the diagnosis of Alzheimer's disease. Am J Alzheimers Dis Other Demen (2014) 30(8):738-45. doi:10.1177/1533317513520214

90. Patton N, Aslam T, Macgillivray T, Pattie A, Deary IJ, Dhillon B. Retinal vascular image analysis as a potential screening tool for cerebrovascular disease: a rationale based on homology between cerebral and retinal microvasculatures. J Anat (2005) 206:319-48. doi:10.1111/j.1469-7580.2005.00395.x

91. De La Torre JC. Is Alzheimer's disease a neurodegenerative or a vascular disorder? Data, dogma, and dialectics. Lancet Neurol (2004) 3:184-90. doi:10.1016/S1474-4422(04)00683-0

92. Berisha F, Feke GT, Trempe CL, McMeel JW, Schepens CL. Retinal abnormalities in early Alzheimer's disease. Invest Ophthalmol Vis Sci (2007) 48:2285-9. doi:10.1167/iovs.06-1029

93. Cheung CY, Ong YT, Ikram MK, Ong SY, Li X, Hilal S, et al. Microvascular network alterations in the retina of patients with Alzheimer's disease. Alzheimers Dement (2014) 10:135-42. doi:10.1016/j.jalz.2013.06.009

94. Williams MA, McGowan AJ, Cardwell CR, Cheung CY, Craig D, Passmore P, et al. Retinal microvascular network attenuation in Alzheimer's disease. Alzheimers Dement (Amst) (2015) 1:229-35. doi:10.1016/j.dadm.2015.04.001

95. Feke GT, Hyman BT, Stern RA, Pasquale LR. Retinal blood flow in mild cognitive impairment and Alzheimer's disease. Alzheimers Dement (Amst) (2015) 1:144-51. doi:10.1016/j.dadm.2015.01.004

96. Einarsdottir A, Hardarson SH, Kristjansdottir JV, Bragason DT, Snaedal J, Stefánsson E. Retinal oximetry imaging in Alzheimers disease. J Alzheimers Dis (2015) 49:79-83. doi:10.3233/JAD-150457

97. Hinton DR, Sadun AA, Blanks JC, Miller CA. Optic-nerve degeneration in Alzheimer's disease. N Engl JMed (1986) 315:485-7. doi:10.1056/ NEJM198608213150804

98. Kirbas S, Turkyilmaz K, Anlar O, Tufekci A, Durmus M. Retinal nerve fiber layer thickness in patients with Alzheimer disease. J Neuroophthalmol (2013) 33:58-61. doi:10.1097/WNO.0b013e318267fd5f

99. Paquet C, Boissonnot M, Roger F, Dighiero P, Gil R, Hugon J. Abnormal retinal thickness in patients with mild cognitive impairment and Alzheimer's disease. Neurosci Lett (2007) 420:97-9. doi:10.1016/j.neulet.2007.02.090

100. Kesler A, Vakhapova V, Korczyn AD, Naftaliev E, Neudorfer M. Retinal thickness in patients with mild cognitive impairment and Alzheimer's disease. Clin Neurol Neurosurg (2011) 113:523-6. doi:10.1016/j. clineuro.2011.02.014

101. Parisi V, Restuccia R, Fattapposta F, Mina C, Bucci MG, Pierelli F. Morphological and functional retinal impairment in Alzheimer's disease patients. Clin Neurophysiol (2001) 112:1860-7. doi:10.1016/ S1388-2457(01)00620-4

102. Iseri $\mathrm{PK}$, Altinaş $\mathrm{O}$, Tokay $\mathrm{T}$, Yüksel N. Relationship between cognitive impairment and retinal morphological and visual functional abnormalities in Alzheimer disease. J Neuroophthalmol (2006) 26:18-24. doi:10.1097/01. wno.0000204645.56873.26

103. Liu D, Zhang L, LiZ, Zhang X, Wu Y, Yang H, et al. Thinner changes of the retinal nerve fiber layer in patients with mild cognitive impairment and Alzheimer's disease. BMC Neurol (2015) 15:14. doi:10.1186/s12883-015-0268-6

104. Coppola G, Di Renzo A, Ziccardi L, Martelli F, Fadda A, Manni G, et al. Optical coherence tomography in Alzheimer's disease: a meta-analysis. PLoS One (2015) 10:e0134750. doi:10.1371/journal.pone.0134750

105. Bambo MP, Garcia-Martin E, Pinilla J, Herrero R, Satue M, Otin S, et al. Detection of retinal nerve fiber layer degeneration in patients with Alzheimer's disease using optical coherence tomography: searching new biomarkers. Acta Ophthalmol (2014) 92:e581-2. doi:10.1111/aos.12374

106. Liu B, Rasool S, Yang Z, Glabe CG, Schreiber SS, Ge J, et al. Amyloid-peptide vaccinations reduce $\beta$-amyloid plaques but exacerbate vascular deposition and inflammation in the retina of Alzheimer's transgenic mice. Am J Pathol (2009) 175:2099-110. doi:10.2353/ajpath.2009.090159

107. Ong YT, Hilal S, Cheung CY, Venketasubramanian N, Niessen WJ, Vrooman H, et al. Retinal neurodegeneration on optical coherence tomography and cerebral atrophy. Neurosci Lett (2015) 584:12-6. doi:10.1016/j. neulet.2014.10.010 
108. Hsiao K, Chapman P, Nilsen S, Eckman C, Harigaya Y, Younkin S, et al. Correlative memory deficits, Abeta elevation, and amyloid plaques in transgenic mice. Science (1996) 274:99-102. doi:10.1126/science.274.5284.99

109. Shimazawa M, Inokuchi Y, Okuno T, Nakajima Y, Sakaguchi G, Kato A, et al. Reduced retinal function in amyloid precursor protein-over-expressing transgenic mice via attenuating glutamate-N-methyl-D-aspartate receptor signaling. J Neurochem (2008) 107:279-90. doi:10.1111/j.1471-4159.2008.05606.x

110. Ning A, Cui J, To E, Ashe KH, Matsubara J. Amyloid-beta deposits lead to retinal degeneration in a mouse model of Alzheimer disease. Invest Ophthalmol Vis Sci (2008) 49:5136-43. doi:10.1167/iovs.08-1849

111. Maia LF, Kaeser SA, Reichwald J, Hruscha M, Martus P, Staufenbiel M, et al. Changes in amyloid- $\beta$ and Tau in the cerebrospinal fluid of transgenic mice overexpressing amyloid precursor protein. Sci Transl Med (2013) 5:194re2. doi:10.1126/scitranslmed.3006446

112. Koronyo Y, Salumbides BC, Black KL, Koronyo-Hamaoui M. Alzheimer's disease in the retina: imaging retinal $A \beta$ plaques for early diagnosis and therapy assessment. Neurodegener Dis (2012) 10:285-93. doi:10.1159/000335154

113. Loffler KU, Edward DP, Tso MO. Immunoreactivity against tau, amyloid precursor protein, and beta-amyloid in the human retina. Invest Ophthalmol Vis Sci (1995) 36:24-31.

114. Koronyo-Hamaoui M, Koronyo Y, Ljubimov AV, Miller CA, Ko MK, Black KL, et al. Identification of amyloid plaques in retinas from Alzheimer's patients and noninvasive in vivo optical imaging of retinal plaques in a mouse model. Neuroimage (2011) 54:S204-17. doi:10.1016/j.neuroimage.2010.06.020

115. La Morgia C, Ross-Cisneros F, Koronyo Y, Hannibal J, Gallassi R, Cantalupo G, et al. Melanopsin retinal ganglion cell loss in Alzheimer's disease. Ann Neurol (2016) 79:90-109. doi:10.1002/ana.24548

116. Ding JJ, Lin J, Mace BE, Herrmann R, Sullivan P, Bowes Rickman C, et al. Targeting age-related macular degeneration with Alzheimer's disease based immunotherapies: anti-amyloid-b antibody attenuates pathologies in an age-related macular degeneration mouse model. Vision Res (2008) 48:339-45. doi:10.1016/j.visres.2007.07.025

117. Zhao Y, Bhattacharjee S, Jones BM, Hill JM, Clement C, Sambamurti K, et al. Beta-amyloid precursor protein ( $\beta \mathrm{APP})$ processing in Alzheimer's disease (AD) and age-related macular degeneration (AMD). Mol Neurobiol (2015) 52:533-44. doi:10.1007/s12035-014-8886-3

118. Ritchie C, Peto T, Barzegar-Befroei N, Csutak A, Ndhlovu P, Wilson D, et al. Peripheral retinal drusen as a potential surrogate marker for Alzheimer's dementia: a pilot study using ultra-wide angle imaging. Invest Ophthalmol Vis Sci (2011) 52(14):6683.

119. Aslam A, Peto T, Barzegar-Befroei N, Gregory S, Morrison G, Ritchie C, et al. Assessing peripheral retinal drusen progression in Alzheimer's dementia: a pilot study using ultra-wide field imaging. Invest Ophthalmol Vis Sci (2014) 55(13):659.

120. Park SW, Kim JH, Park SM, Moon M, Lee KH, Park KH, et al. RAGE mediated intracellular $\mathrm{A} \beta$ uptake contributes to the breakdown of tight junction in retinal pigment epithelium. Oncotarget (2015) 6:35263-73. doi:10.18632/ oncotarget.5894

121. Park SW, Kim JH, Mook-Jung I, Kim KW, Park WJ, Park KH, et al. Intracellular amyloid beta alters the tight junction of retinal pigment epithelium in 5XFAD mice. Neurobiol Aging (2014) 35:2013-20. doi:10.1016/j. neurobiolaging.2014.03.008

122. Bruban J, Glotin AL, Dinet V, Chalour N, Sennlaub F, Jonet L, et al. Amyloid- $\beta$ (1-42) alters structure and function of retinal pigmented epithelial cells. Aging Cell (2009) 8:162-77. doi:10.1111/j.1474-9726.2009.00456.x

123. Dinet V, Bruban J, Chalour N, Maoui A, An N, Jonet L, et al. Distinct effects of inflammation on gliosis, osmohomeostasis, and vascular integrity during amyloid beta-induced retinal degeneration. Aging Cell (2012) 11:683-93. doi:10.1111/j.1474-9726.2012.00834.x

124. Bruban J, Maoui A, Chalour N, An N, Jonet L, Feumi C, et al. CCR2/CCL2mediated inflammation protects photoreceptor cells from amyloid- $\beta$-induced apoptosis. Neurobiol Dis (2011) 42:55-72. doi:10.1016/j.nbd.2011.01.004

125. Wang J, Ohno-Matsui K, Yoshida T, Shimada N, Ichinose S, Sato T, et al. Amyloid $\beta$ up-regulates complement factor B in retinal pigment epithelial cells through cytokines released from recruited macrophages/microglia: another mechanism of complement activation in age-related macular degeneration. J Cell Physiol (2009) 220:119-28. doi:10.1002/jcp.21742

126. Johnson LV. The Alzheimer's Abeta-peptide is deposited at sites of complement activation in pathologic deposits associated with aging and age-related macular degeneration. Proc Natl Acad Sci U S A (2002) 99:11830-5. doi:10.1073/pnas.192203399

127. McHarg S, Clark S, Day A, Bishop P. Age-related macular degeneration and the complement system. Immunobiology (2012) 67:43-50. doi:10.1016/j. imbio.2011.07.019

128. Aiyaz M, Lupton MK, Proitsi P, Powell JF, Lovestone S. Complement activation as a biomarker for Alzheimer's disease. Immunobiology (2012) 217:204-15. doi:10.1016/j.imbio.2011.07.023

129. Samura E, Shoji M, Kawarabayashi T, Sasaki A, Matsubara E, Murakami T, et al. Enhanced accumulation of tau in doubly transgenic mice expressing mutant betaAPP and presenilin-1. Brain Res (2006) 1094:192-9. doi:10.1016/j.brainres.2005.12.134

130. Oddo S, Caccamo A, Shepherd JD, Murphy MP, Golde TE, Kayed R, et al. Triple-transgenic model of Alzheimer's disease with plaques and tangles: intracellular A $\beta$ and synaptic dysfunction. Neuron (2003) 39:409-21. doi:10.1016/S0896-6273(03)00434-3

131. Zhao H, Chang R, Che H, Wang J, Yang L, Fang W, et al. Hyperphosphorylation of tau protein by calpain regulation in retina of Alzheimer's disease transgenic mouse. Neurosci Lett (2013) 551:12-6. doi:10.1016/j.neulet.2013.06.026

132. Ferreira A. Calpain dysregulation in Alzheimer's disease. ISRN Biochem (2012) 2012:728571. doi:10.5402/2012/728571

133. Gasparini L, Crowther RA, Martin KR, Berg N, Coleman M, Goedert M, et al. Tau inclusions in retinal ganglion cells of human P301S tau transgenic mice: effects on axonal viability. Neurobiol Aging (2011) 32:419-33. doi:10.1016/j. neurobiolaging.2009.03.002

134. Blanks JC, Torigoe Y, Hinton DR, Blanks RHI. Retinal pathology in Alzheimer's disease. I. Ganglion cell loss in foveal/parafoveal retina. Neurobiol Aging (1996) 17:377-84. doi:10.1016/0197-4580(96)00010-3

135. Chiu K, Chan TF, Wu A, Leung IY, So KF, Chang RC. Neurodegeneration of the retina in mouse models of Alzheimer's disease: what can we learn from the retina? Age (Omaha) (2012) 34:633-49. doi:10.1007/s11357-0119260-2

136. Edwards MM, Rodríguez JJ, Gutierrez-Lanza R, Yates J, Verkhratsky A, Lutty GA. Retinal macroglia changes in a triple transgenic mouse model of Alzheimer's disease. Exp Eye Res (2014) 127:252-60. doi:10.1016/j. exer.2014.08.006

137. Tsai Y, Lu B, Ljubimov AV, Girman S, Ross-Cisneros FN, Sadun AA, et al. Ocular changes in TGF344-AD rat model of Alzheimer's disease. Invest Ophthalmol Vis Sci (2014) 55:523-34. doi:10.1167/iovs.13-12888

138. Cordeiro MF, Migdal C, Bloom P, Fitzke FW, Moss SE. Imaging apoptosis in the eye. Eye (Lond) (2011) 25(5):545-53. doi:10.1038/eye.2011.64

139. Cordeiro MF, Guo L, Coxon KM, Duggan J, Nizari S, Normando EM, et al. Imaging multiple phases of neurodegeneration: a novel approach to assessing cell death in vivo. Cell Death Dis (2010) 1:e3. doi:10.1038/cddis.2009.3

140. Jentsch S, Schweitzer D, Schmidtke KU, Peters S, Dawczynski J, Bär KJ, et al. Retinal fluorescence lifetime imaging ophthalmoscopy measures depend on the severity of Alzheimer's disease. Acta Ophthalmol (2015) 93:e241-7. doi:10.1111/aos.12609

141. Shaun Frost S, Kanagasingam Y, Macaulay L, Koronyo-Hamaoui M, Koronyo Y, Biggs D, et al. Retinal amyloid fluorescence imaging predicts cerebral amyloid burden and Alzheimer's disease. Alzheimers Dement (2014) 10:234-5. doi:10.1016/j.jalz.2014.04.341

142. Lengyel I, Csutak A, Florea D, Leung I, Bird AC, Jonasson F, et al. A population-based ultra-widefield digital image grading study for age-related macular degeneration-like lesions at the peripheral retina. Ophthalmology (2015) 122:1340-7. doi:10.1016/j.ophtha.2015.03.005

143. Lengyel I, Quinn NB, Csincsik L, Ritchie C, Hogg RE, Crutch S, et al. Retinal image analysis and Alzheimer's disease. Invest Ophthalmol Vis Sci (2015) 56:2795.

144. Jha P, Banda H, Tytarenko R, Bora PS, Bora NS. Complement mediated apoptosis leads to the loss of retinal ganglion cells in animal model of glaucoma. Mol Immunol (2011) 48:2151-8. doi:10.1016/j.molimm.2011.07.012

145. Gharbiya M, Trebbastoni A, Parisi F, Manganiello S, Cruciani F, D’Antonio F, et al. Choroidal thinning as a new finding in Alzheimer's disease: evidence from enhanced depth imaging spectral domain optical coherence tomography. J Alzheimers Dis (2014) 40:907-17. doi:10.3233/JAD-132039

146. Blanks JC, Hinton DR, Sadun AA, Miller CA. Retinal ganglion cell degeneration in Alzheimer's disease. Brain Res (1989) 501:364-72. doi:10.1016/0006-8993(89)90653-7 
147. Blanks JC, Schmidt SY, Torigoe Y, Porrello KV, Hinton DR, Blanks RH. Retinal pathology in Alzheimer's disease. II. Regional neuron loss and glial changes in GCL. Neurobiol Aging (1996) 17:385-95. doi:10.1016/0197-4580(96)00009-7

148. Tsai CS, Ritch R, Schwartz B, Lee SS, Miller NR, Chi T, et al. Optic nerve head and nerve fiber layer in Alzheimer's disease. Arch Ophthalmol (1991) 109:199-204. doi:10.1001/archopht.1991.01080020045040

149. Lu Y, Li Z, Zhang X, Ming B, Jia J, Wang R, et al. Retinal nerve fiber layer structure abnormalities in early Alzheimer's disease: evidence in optical coherence tomography. Neurosci Lett (2010) 480:69-72. doi:10.1016/j. neulet.2010.06.006

150. Bamboo MP, Garcia-Martin E, Gutierrez-Ruiz F, Pinilla J, Perez-Olivan S, Larrosa JM, et al. Analysis of optic disk color changes in Alzheimer's disease: a potential new biomarker. Clin Neurol Neurosurg (2015) 132:68-73. doi:10.1016/j.clineuro.2015.02.016

151. Danesh-Meyer HV, Birch H, Ku JY-F, Carroll S, Gamble G. Reduction of optic nerve fibers in patients with Alzheimer disease identified by laser imaging. Neurology (2006) 67:1852-4. doi:10.1212/01.wnl.0000244490.07925.8b

152. Goozee KG, Shah TM, Sohrabi HR, Rainey-Smith SR, Brown B, Verdile G, et al. Examining the potential clinical value of curcumin in the prevention and diagnosis of Alzheimer's disease. Br J Nutr (2015) 1:1-17. doi:10.1017/ S0007114515004687
153. Lee JY, Ahn J, Kim TW, Jeon BS. Optical coherence tomography in Parkinson's disease: is the retina a biomarker? J Parkinsons Dis (2014) 4:197-204. doi: 10.3233/JPD-130306

154. Pache M, Smeets CH, Gasio PF, Savaskan E, Flammer J, Wirz-Justice A, et al. Colour vision deficiencies in Alzheimer's disease. Age Ageing (2003) 32:422-6. doi:10.1093/ageing/32.4.422

155. Cronin-Golomb A, Corkin S, Rizzo JF, Cohen J, Growdon JH, Banks KS. Visual dysfunction in Alzheimer's disease: relation to normal aging. Ann Neurol (1991) 29:41-52. doi:10.1002/ana.410290110

Conflict of Interest Statement: The authors declare that the research was conducted in the absence of any commercial or financial relationships that could be construed as a potential conflict of interest.

Copyright (C) 2016 Javaid, Brenton, Guo and Cordeiro. This is an open-access article distributed under the terms of the Creative Commons Attribution License (CC BY). The use, distribution or reproduction in other forums is permitted, provided the original author(s) or licensor are credited and that the original publication in this journal is cited, in accordance with accepted academic practice. No use, distribution or reproduction is permitted which does not comply with these terms. 